Karadeniz Uluslararası Bilimsel Dergi

Volume: 46, Summer-2020, p. (257-270)

ISSN: 1308-6200 DOI: https://doi.org/10.17498/kdeniz.644268

Research Article

Received: November 8, 2019| Accepted: May 22, 2020

This article was checked by intihal.net.

\title{
YENİ KENTLİLEŞME SÜRECINDE KENTLİ KARAKTER(LER)İN SOSYOLOJİK YANSIMALARI
}

\section{SOCIOLOGICAL REFLECTIONS OF URBAN CHARACTER(S) IN NEW URBANIZATION PROCESS}

\author{
СОЦИОЛОГИЧЕСКИЕ РАЗМЫШЛЕНИЯ О ХАРАКТЕРЕ(АХ) \\ ГОРОДСКИХ ЖИТЕЛЕЙ В ПРОЦЕССЕ НОВОЙ УРБАНИЗАЦИИ
}

Hatice GÜL*

\section{ÖZ}

Kentler her türlü faaliyetlerin merkezi olduğu kadar bireyin yaşam tarzı ve karakterinin de şekillendiği merkezlerdir. Kentler var olduğu tarihsel süreçten bu yana düşüncelerimizi, davranışlarımızı, başkalarıyla ve diğer çevresel dinamiklerle olan ilişkilerimizi etkileyen ve kendine özgü yaşam biçimlerini oluşturan yerlerdir. Bununla birlikte kentler toplumsal değişimlerin yoğun bir şekilde yaşandığı alanlar olarak hâlen gündemini korumaktadır. Kentsel yaşam tarzına özgü değer yargıları, davranışları ve tutumları kaçınılmaz olarak yaşanan toplumsal değişimlerden nasibini almaktadır. Değişimin en belirgin özelliği, kentli karakterlerin sosyal yaşamda yeni formlarla karşımıza çıkmasıdır. Kentli olmak değişmekte olan düzenin bir parçası olmaktır. Nitekim birey yaşadığı kentsel koşullarda gerçekleşen değişim dinamikleri üzerinden karakterini ortaya koymaktadır. Yaşanan değişimin öbeğinde bireyin olması değişimden en çok da bireyin etkilendiğinin bir göstergesidir. Çalışmamızda yeni kapitalist sistemin kent üzerindeki etkilerinin bir tezahürü olarak ortaya çıan maneviyat arayışları ve yeni kentlileşme arasındaki ilişkinin boyutları ortaya konmuştur. Bu bağlamda kapitalist kentleşme ile yeni tutum ve alışkanlıklar kazanan bireyin karakterine atfedilen başlıca nitelikler, R. Sennett, Z. Bauman ve E. Fromm'un bakış açıları dikkate alınarak irdelenmiştir. Değerlendirme sonucunda her üç yazarın karakter üzerinde yoğunlaştığ1 belirgin noktalar öne çıkmakla birlikte bazı özellikler de benzerlikler göstermektedir. Benzer nitelikler arasında "tüketici eğilime yatkın, yüzeysel ve geçici ilişkilere sahip, esnek ve değişime açık olma, hedeflerini kısa süreli tutma vb.” özelliklerin ortaya çıktığını söylemek mümkündür.

Anahtar Kelimeler: Yeni Kentlileşme, Karakter, Kapitalizm, Esneklik, Maneviyat

* ORCID: 0000-0001-5905-3850, Dr., hgul11212@gmail.com 


\section{Yeni Kentlileşme Sürecinde Kentli Karakter(ler)in Sosyolojik Yansımaları}

\section{ABSTRACT}

Cities are also shaped centers of individual's lifestyle and character as well as the center of all kinds of activities. Cities are the places that have influenced our thoughts, behaviors, our relationships with others, and other environmental dynamics since the historical process and create their own lifestyles. In addition, cities still maintain their agenda as areas where social changes are experienced intensively. The value judgments, behaviors, and attitudes specific to the urban lifestyle are inevitably affected by social changes experienced. The most distinctive feature of the change is the emergence of urban characters with new forms in social life. Being urban is to be a part of the changing order. As a matter of fact, the individual reveals his character through the dynamics of change taking place in the urban conditions in which he lives. The fact that the individual is at the center of the change is an indicator that the individual is most affected by the change. In our study, the dimensions of the relationship between the spirituality seekings and the new urbanization that emerged as a manifestation of the effects of the new capitalist system on the city have been revealed. In this context, the main features attributed to the character of the individual who gained new attitudes and habits by capitalist urbanization have been examined by taking into consideration the perspectives of R. Sennett, Z. Bauman, and E. Fromm. As a result of the evaluation, along with the prominence of the salient points on which all three writers focus on the character, some features also show similarities. Among the similar qualities, it is possible to say that there are features that are prone to consumer, having superficial and temporary relationships, being flexible and open to change, holding short-term goals, and so on."

Keywords: New Urbanization, Character, Capitalism, Flexibility, Spirituality

\section{АННОТАЦИЯ}

Города, это центры всех видов деятельности, а также места, где формируется образ жизни и характер людей. Города-это те места, которые оказали влияние на наши мысли, поведение, взаимоотношения с другими людьми и динамику окружающей среды с момента исторического процесса, в котором они существовали, и формируют свой уникальный образ жизни. К тому же, города как область интенсивных социальных изменений, по-прежнему сохраняет свою повестку дня. Оценочные суждения, поведение и менталитет, характерные для городского образа жизни, неизбежно подвержены влиянию социальных изменений. Наиболее отличительной чертой изменения является появление городских персонажей в новых формах общественной жизни. Быть городским - значит быть частью изменений. Фактически, характер индивидуума раскрывается через динамику изменений, происходящих в городских условиях, в которых он живет. Тот факт, что индивидуум находится в центре изменений, является показателем того, что индивидуум больше всего подвержен изменениям. В ходе нашего исследования были раскрыты аспекты взаимосвязи между поиском духовности и новой урбанизации, как проявление влияния новой капиталистической системы на город. В данном контексте, основные черты характера индивида, приобретшего новые позиции и привычки в результате капиталистической урбанизации, были рассмотрены с учетом взглядов Р. Сеннетта, 3. Баумана и Э. Фромма. В результате оценки, наряду с выдающимся положением важных черт характера, на которых сосредотачиваются все три автора, некоторые черты также показывают сходство. Можно сказать, что среди подобных качеств есть черты, склонные к потребительству, имеющие поверхностные и временные отношения, гибкие и открытые к изменениям, имеющие краткосрочные цели и т.п.” Ключевые слова: Новая Урбанизация, Характер, Капитализм, Гибкость, Духовность 


\section{Giriş}

Modernlikle birlikte yaygınlaşan maneviyat arayışları beraberinde farklılaşan yeni yaşam tarzları ve benlik formlarının pratiğe sokulmasına yol açmıştır. Tarihsel gelişimi içinde bireyin sürekli olarak manevi boyuta ilişkin bir arayış içinde olduğu açıktır. Daha çok insani varoluşa kaynak teşkil eden maneviyat arayışlarını, modernite bağlamından ayrı düşünmek olgusal duruma aykırı gözükmektedir. Bu çalışmada maneviyat arayışlarına farklı bir boyut getiren yeni kapitalist kentleşme ile yeni tutum ve alışkanlıklar kazanan birey(ler)in karakter(ler)i ile ilgili olarak R. Sennett, Z. Bauman ve E. Fromm'un düşünceleri irdelenmiş ve buradan hareketle yeni kentli karakter(ler)inin belirgin özellikleri öne çıkarılmaya çalışılmıştır.

Kentler ve yeni oluşan kentsel yapılanmalar arasında yakın ilişkiler bulunması, kent sakinlerinin de bu süreçten nasıl etkilendiğini bize göstermektedir. Genelde kent ve toplumsal ilişkiler, özelde ise kent ve birey arasındaki etkileşimin boyutu, sürekli ve dinamik bir ilişki olarak görülebilir. Etkileşim aynı zamanda "değişimi” ve "gelişimi”" de beraberinde taşır. Nitekim Harvey (2013: 277), bu konuya dikkat çekerek kentsel yapının yaratılmasıyla birlikte toplumsal ilişkiler ve üretim örgütlenmesinin gelecekteki gelişimlerinin etkilendiğini ifade etmektedir. Öte yandan bireyin değişime açık olması, onu, kentsel koşullarda birtakım zorluklara maruz bırakmaktadır. Bu zorluklarla baş başa kalan bireyin yeni kente uyum sağlama gayreti, beraberinde bu uyumu sağlayacak yeni kültürel formların ortaya çıkmasına imkân vermektedir. Yeni davranış kalıpları ve yaşam tarzları, söz konusu değişimle birlikte tüketici ve bireyci maneviyat arayışlarına da kapı aralamaktadır. Bu sebeple yeni kapitalizmin tüketici bir toplum yaratmadaki etkisini göz önünde bulundurmak, çağın karakteristiğini anlamak açısından önemlidir. Zira kapitalizmle birlikte değişmekte olan kentler tek bir yaşam tarzına sahip değildir. Nitekim günümüz kentsel toplumun karakteristiği heterojen bir yapı arz etmekte olup yabancılarla ve bilinmeyenlerle karşılaşma ve temas süreci, psikolojik şokların, sorunların ve sürprizlerin yaşandığı bir mecrayı oluşturmaktadır (Robins, 1996: 131). Dolayısıyla tek bir yaşam tarzı, kentlerinin ayırıcı bir özelliği olmadığı gibi öngörülemeyen gelecek, bizi, risklerle ve kaygılarla dolu bir dünya ile baş başa bırakmaktadır. Bu çalışmada yeni kapitalist kentleşmenin, birey(ler) üzerindeki etkileri göz önünde tutularak Sennett, Bauman ve Fromm'un çağdaş insanın karakteri ile ilgili düşünceleri ortaya konmuştur. Bu bağlamda öncelikle yeni kentlileşme ve maneviyat arayışları arasındaki ilişkinin içeriğine değinilmiş, sonra ise Sennett, Bauman ve Fromm'un yeni kentli karakter(ler)iyle ilgili düşüncelerine yer verilerek belirgin ve ortak özellikler ortaya konmaya çalışılmıştır.

\section{Yeni Kentlileşme ve Maneviyat Arayışları İlişkisi}

Maneviyat arayışları ve kent arasındaki ilişkinin mahiyetini toplumsal ve kültürel olarak kapitalist anlayışın kapsamından koparmak mevcut koşulların birey üzerindeki etkilerini göz ardı etmek olur. Nitekim kentleşme sürecinde birey üzerinde derin etkiler bırakan başlıca toplumsal değişimlerden biri, yeni/örgütsüz 


\section{Yeni Kentlileşme Sürecinde Kentli Karakter(ler)in Sosyolojik Yansımaları}

kapitalizmdir. $\mathrm{Bu}$ terim gelişmiş kapitalizmin ekonomisi, devleti ve sivil toplumunun sosyoekonomik gruplarında meydana gelen parçalanmışlığ ifade etmek için J. Urry, S. Lash ve C. Offe gibi sosyologlar tarafından kullanılmıştır (Marshall, 1999: 564). Lash ve Urry’ye göre (akt. Kumar, 1999: 66-67) örgütsüz (disorganized) kapitalizm, yeni bir evre olup kapitalizmin yeni koşullar altında sistematik olarak yeniden yapılanmasıdır. Başka bir deyişle toplumların sınıf, endüstri, ulus-devlet gibi katı unsurlarının yanı sıra bunlar arasındaki sabit ve donuk ilişkilerin baştan aşağı değiş̧ip buharlaşmasıdır. Yeni kapitalist sistem sadece kentin sosyokültürel ve sosyoekonomik gerçekliğini yeniden şekillendirmekle kalmayıp, aynı zaman da bireyin yaşam tarzı ve davranış kodlarında da değişimlere yol açmaktadır. Yeni kapitalizm ile birlikte ilişkili olan ve ele alınması gereken önemli bir kavram ise yeni kentlileşmedir. Yeni kentlileşmenin tanımını yapmadan önce kentlileşmenin genel bir tanımını yapmak gerekir. Keleş'e (1980: 70-71) göre kentlileşme, kentleşme sonucunda ortaya çıkan toplumsal değişmelerin insanların davranışlarında, ilişkilerinde, değer yargılarında, manevi ve maddi yaşam biçimlerinde değişiklikler yaratan bir süreç, Güneş'e (2016: 149) göre ise "kent kültürüne ait değer, davranış ve tutumların benimsenmesi"dir. Her ne kadar kentlileşmenin tanımı güncelliğini korumakta ise de yeni kapitalizm gerçeğiyle birlikte kentlileşmenin de mahiyeti değişmiştir. Bu sebeple eski kentlileşmede, kente yeni gelenlerin sosyalizasyonunda ve uyum sürecinde sergiledikleri davranış ve eğilimlerinde, yakın akraba ve çevresel dayanışma ağlarının etkisi görülürken, yeni kentlileşmede daha çok kente uyum sağlama tecrübelerinin bireysel çabalarla sürdürüldüğü bir boyut belirginleşmektedir. Bir başka deyişle yeni kentlileşme, yeni kapitalist sistemin yoğun etkileri altında gelişen tüketim eğilimlerinin kentli sosyal grup, aile ve bireyler üzerindeki etkileriyle şekillenmekte olup, bireyin kente uyum sağlama yeteneklerinin giderek daha bireyselleştiği bir sürece işaret etmektedir (Gül, 2019: 15). Bu yeni kapitalist yapılanmanın ayırt edici özelliğgi ise esneklik anlayışıdır. Bu esnek tutum kapitalizm için baştan aşağı kendini yeniden yaratmanın yolunu açmıştır. Bu anlamda kapitalist sistemin, kente dair bireysel ve toplumsal yaşamın tümünü kuşattığını ve yeni davranış kodları yarattığını söylemek yanlış olmayacaktır. Dolayısıyla yeni kapitalist kavramına koşut olarak yeni kentlileşme kavramından da bahsedilebilir.

Modern toplumun bir yönü de bireyselleşme ile ilgili olmasıdır (Berger, 2017: 606). Bireyselleşme ve yeni kapitalizmin karakteristiği olan esneklik arasında doğrudan bir ilişki bulunmaktadır. Başka bir deyişle esnek yapı bireysellik üzerinde önemli bir etkiye sahiptir. Bunu ise daha çok tüketim üzerinden bireylere birçok seçenek ve firsatlar sunma yoluyla gerçekleştirmektedir. Bu bağlamda kentin sosyal, kültürel, siyasi ve manevi etmenlerle ilişkisini sağlayan süreç, yeni kapitalist sistemin egemenliğini sağlamlaştırdığı bir döneme tekabül eder. Bu süreç yeni bireysel formların, aidiyet bağlarının, dolayısıyla yeni maneviyat arayışlarının da tezahür ettiği bir süreçtir. Bu bağlamda bireyin sosyo-psikolojik durumunu anlamaya çalışırken kapitalist sistemin aynı zamanda kendi içinde sistemin sorunlarına getirdiği çözümleri de bu sürecin karmaşık ve çelişkili yapısında aramak gerekir. 
Nitekim günümüzün maneviyat eğilimleri de bu sürecin karmaşık doğasının bir parçası olarak yeni benlik formları yaratmaktadır.

Maneviyat arayışlarından kastedilen esasen çeşitlenen yeni benlik formlarının çevreye yansımış tezahürleridir. Günümüzde maneviyat terimi, daha çok geleneksel dinde meydana gelen değişimler veya spesifik tezahürlerle öne çıkmıştır. $\mathrm{Bu}$ bağlamda gittikçe kendisinden daha fazla söz ettiren maneviyat olgusuna yaklaşımlar oldukça dikkat çekicidir. Paul Heelas'ın din ve maneviyat tanımından, maneviyatın içeriği ile ilgili açık bir ifade görmek mümkündür. Ona göre din, aşkın bir Tanrı'ya itaat ve O'nun hâkimiyetini sürdüren bir gelenek iken maneviyat ise "kişiselle ilgilidir; iç (interior) ya da içkindir (immanent); bireyin kutsal ile bağlantı kurma tecrübesidir ve bu tür tecrübelerden türeyen bir hikmet veya bilgidir" (Hamberg, 2012: 235). Bir başka deyişle maneviyat, hayat anlamına gelmekle birlikte hayatın içindeki kutsalı tecrübe etmektir. Pargament (2015: 376-377) ise maneviyatın, dinin kalbi ve ruhu olduğunu öne sürmektedir. Ona göre maneviyat kutsalın aranmasıdır. Maneviyat da din gibi bireysel ve kurumsal olarak tecrübe edildiği gibi geleneksel ve geleneksel olmayan formlara da girebilir, iyi ya da kötü de olabilir. Georg Simmel'in maneviyat yaklaşımı ise günümüz maneviyat anlayışına daha anlaşılır bir açıklık getirmesi bakımından önemli gözükmektedir. Simmel için dindarlık, özel bir varoluştur ve yaşamı tecrübe eden insan ruhunun bir formudur. İnançlı insan Tanrı'ya inansa da inanmasa da dindar olabilir. Bir başka deyişle maneviyat, üstün bir varlığa inanma gereksinimi olmadan da kişinin dünyaya bakış açısını ifade eder (Simmel'den akt. Varga, 2007: 151). Maneviyat, genellikle din bağlamında ortaya çıtığı gibi din dışı bağlamda da ortaya çıkabilmektedir. Aynı sebeple insanlar, maneviyatı tecrübe etme süreçleri sonucunda dinin bir üyesi de olabilirler veya olmayabilirler (Hill ve diğerleri, 2013: 109). Esasen bu ifadelerden görüldüğü üzere maneviyatın hem dinî hem de din dışı bir anlayışı kapsadığı anlaşılmaktadır. Bilindiği gibi modern öncesi geleneksel toplumların maneviyat arayışlarında Tanrı ve insanın varoluş gerçeği göze çarpmaktaydı. Bir başka deyişle modern öncesi zamanların maneviyat arayışlarında bireyin varoluşunu anlamlandırma arayışları söz konusuydu. Oysa günümüzün maneviyat arayışları ise modern kişinin "ne aradığını" öngöremediği bir evreye doğru kaymıştır. Kültürel iklimi bireysel olan kent ortamında, maneviyat arayışları bir şekilde bireylerin özgür seçimlerinin geniş yelpazesi içinde belirsizlikleri, kırılmaları ve tatminsizlikleri içermektedir. Bu arada din de bireyselleşmiş, bir başka ifadeyle bireysel maneviyat anlayışları ve yorumları da zamanla çeşitlenmiştir. Modern yaşam bireyi, kentin kalabalığında daha önceki dini kabullerinden sıyırarak özgürlük ortamına itmiş̧ir. Taylor'ın ifadesiyle önceleri "Tanrı'yla öncelikle toplum olarak ilişki kuruyor" (2006: 60) iken din de toplumun kolektif bir şekilde icrasıydı. Eski zamanlarda aileye veya bir cemaate bağl1lık yaşamı anlamlı kılarken, modern toplumda hayatı anlamlı kılacak anlam arayışları çeşitlenmiş ve bireyci bir tüketim anlayışıyla hareket eden insanların sayısı gittikçe artmıştır. Geleneksel toplumda maneviyat arayışının merkezinde "Tanrı" büyük bir önemdeyken, yeni zamanların maneviyat arayışlarının çeşitliliği, eskinin maneviyatının yerini doldurmaya çalışmaktadır. Farklılaşan aşk arayışları, maddi beklentilerin çeşitliliği, gezilecek yeni yerler 


\section{Yeni Kentlileşme Sürecinde Kentli Karakter(ler)in Sosyolojik Yansımaları}

görmek, sivil toplum kuruluşlarına üye olmak, internet üzerinden sosyal ağlarda farklılaşan amaçlar için gezinmek, rekabet, başarı, din veya din dışı anlam arayışları veya sığınılacak maddi ve manevi huzur arayışları gibi durumlar insanların maneviyatlarında giderek daha fazla önemli hale gelebilmektedir. Anlaşılan bir zamanların Tanrı ve din odaklı maneviyatı, çağdaş insanlara yetersiz gelmektedir. Dolayısıyla yeni kentlileşmeyle birlikte manevi yaşamın da bir tercih meselesi olarak ortaya çıktığını belirtmek yanlış olmayacaktır.

Günümüzde kentsel yapı ile birey arasındaki ilişkinin yeni biçimi kapitalist yaklaşımla belirgin bir şekilde öne çıkmaktadır. Ancak kentsel yapı ve birey arasındaki ilişki sabit olmayıp iniş çıkışlıdır. Bu hareketli yapısı, kapitalizmin gücüyle ortaya çıkmakta ve yenilenmektedir. Yeni kapitalizmin birey üzerindeki etkisinin bir ürünü olarak ortaya çıkan kararsızlık, değişkenlik, parçalanmışlık ve güvensizlik gibi duygularla nesneleşen birey, bu süreçte varoluşundan kaynaklı öznel gerçekliğini de bastırmaktadır. Dolayısıyla bireyin öznel gerçekliğinin bastırılması, varoluşunun insani suretinden beşerî suretine indirgenmesi birçok sorunları beraberinde getirmektedir. Ancak bireyin bu şekilde özneden nesneye kayışı da tam anlamıyla duygularından koptuğu anlamına gelmemektedir. Nitekim özne ve nesne arasındaki geçişlilikler de esnek olup söz konusu özne-nesne geçişliliği yeni benlik formlarının çeşitliliğini gündeme getirmektedir.

Yeni kapitalist anlayışın belirgin özelliklerinden biri, özne ve nesne arasındaki geçişlilikleri esnetmesidir. Bu esnek yapı ayrıca özne-nesne arasına sıkıştırılmış günümüz kentli karakter(ler)ini ve yönelimlerini belirleyen önemli bir etmendir. Günümüzde kentsel bireycilik duygusunun neredeyse başat unsurları haline gelmiş olan parçalanmışlık, kaygı, tedirginlik, mutsuzluk ve güvensizlik gibi fenomenlerin de yarattığı etkiler sadece bireylerin kendi hayatlarını anlamlandırma çabasını belirsizleştirmiyor, aynı zamanda arayışların geçiciliğini kimi zamanda anlamsızlığını gündeme getirmektedir. Bu fenomenlerin kent içinde her yere sirayeti nedeniyle bu sürecin dışında kalmak, kent sakinleri için gittikçe zorlaşmaktadır. Nitekim birey için yaşamı idame ettirmenin bir yolu yaşadığı toplumla bir etkileşim sürecini gerekli kıldığından bireyin, yaşanılan değişimlerin dışında kalması mümkün görünmemektedir. Bu değişim sürecinde bireyin yalnızca kendini merkeze aldığı ben merkezci bir eksen oluşturması, maneviyat arayışlarını çeşitlendirmekle birlikte bir kaosun içine sokmaktadır. Bireyin "ne yaptığ 1 veya ne aradığı" ile ilgili eylemlerinde bir istikrarın sağlanamaması konusunda paradoksal bir evren sunan kapitalist anlayış, yarattığ 1 geçici hazlarla beraber tatminsizlik ve doyumsuzluğu da beraberinde getirmektedir. $\mathrm{Bu}$ sebeple maneviyat arayışlarını, bireyin tüketim üzerindeki tatminsizlik ve doyumsuzluk konusundaki kontrolsüzlüğünün bir sonucu olarak da görmek mümkündür.

Yeni kentlileşme dinamiğinin bir diğer ayırt edici özelliği ise yeni teknolojik gelişmelerin birey ve toplum üzerinde oluşturduğu etkilerdir. Özellikle son zamanlarda bilgi ve iletişim teknolojilerinin birey üzerinde yarattığı etkilerin olumlu yönleri kadar olumsuz yönlerinin de olduğu dikkat çekmektedir. Nitekim bilgi ve iletişim teknolojisiyle her şeye ulaşma imkânlarının artması bireylere evden çalı̧abilme, alışveriş yapabilme gibi imkânlar sunarken bir taraftan da birey ve 
toplumu tüketim çılgınlığı ve arayışlarına yöneltebilmektedir. Esasen yeni kentlileşme, içinde geniş bir tercih ve firsat olanağı bulunduran bir sürece de işaret eder. Bu bağlamda yeni kentli karakter(ler)inin çoklu seçenek ve imkânlara da sahip olduğunu söylemek mümkündür (Gül, 2019: 21). Burada tüketim çılgınlığ1 ve arayışların çeşitliliği söz konusudur. Tüketim olgusu eşyaları, malları, toplumsal davranış ve ilişkileri, yaşam tarzları ve kodları, bir başka deyişle tüm yaşamı kuşatarak değiştirir ve düzenler (Baudrillard, 2013: 20). İnsanlar sadece nesneleri değil, birbirlerini, ilişkilerini, arkadaşlıklarını ve hatta evliliklerini de tüketebilmektedir. Dolayısıyla söz konusu maneviyat arayışlarını, yeni kentli bireyin tüketim odaklı yaşam tarzları ve davranış kalıplarıyla ilişkilendirmek bu bağlamda anlamlı gözükmektedir.

\section{Yeni Kentli Karakter(ler)ine R. Sennett, Z. Bauman ve E. Fromm'un Yaklaşımları}

Karakter terimi fen bilimlerinden, sosyal bilimlere kadar birçok disiplinin konu alanına girmiştir. Bundan dolayı her disiplin karakter terimini, kendi çalışma alanına göre farklı tanımlamıştır. Adler "karakteri" sosyal bir kavram olarak vurgulamaktadır. Ona göre bir kişinin çevreyle ilişkisi göz önünde tutulduğunda ancak bir "karakter özelliği”"nden bahsedilebilir. Söz konusu "karakter özelliği denilince, yaşamın karşısına çıkardığ üstesinden gelmeye çalışan bir insanda belirli bir ruhsal dişavurumun ön plana çıkması" (Adler, 2002: 173) anlaşılmaktadır. Fromm (2005: 73-75) ise karakteri "asimilasyon ve toplumsallaşma süreci içinde insan enerjisinin yönlendirildiği bir biçim (nispeten kalıcı)" olarak tanımlar. Fromm, karakteri bireysel karakter ve sosyal karakter diye kategorize eder. Bireysel karakter aynı kültür içinde bireyi, bir diğerinden ayıran özellikler iken sosyal karakter ise belli kültüre ait insanların çoğunda olan ve karakter yapısının çekirdeğini oluşturan ortak toplumsal özelliklerdir. Nitekim din, dil, üretim biçimi, siyaset, eğitim, hukuk, coğrafi konum vb. olgular bireyin karakterinin şekillenmesinde dinamik bir rol oynamaktadır. Sennett'e (2008: 10) göre karakter, “asıl olarak duygusal deneyimlerimizin uzun vadeli boyutu üzerine odaklanır. Karakter kendini, sadakat ve karşılıklı bağlılık, uzun vadeli bir hedef için çaba sarf etme ya da gelecekteki bir amaç uğruna kimi mükâfatları erteleme seklinde gösterir. Her birimiz, herhangi bir özel anda yaşadığımız duygu karmaşasının içinden bazı duygular seçer ve içimizde yaşatırız; yaşadığımız bu duygular karakterimizi oluşturur." Kısacası karakter, "kendimizde değerli bulduğumuz ve başkalarının değer vermesini beklediğimiz özelliklerimizdir” (Sennett, 2008: 10-11). Sennett, kendisinin betimlediği karakter tanımının ötesinde, esnek kapitalizmin yoğun etkileri altında bulunan karakterin, içinde yaşadığımız koşullar karşısında dirençli olup olmadığını sorgular. Ona göre, "Sabırsız, mevcut ana odaklanan bir toplumda, hangi özelliğimizin kalıcı değer taşıdığına nasıl karar verebiliriz? Kısa vadeye kilitlenmiş bir ekonomide nasıl uzun vadeli hedeflere sahip olabiliriz? Her an parçalanan veya sürekli olarak yeniden şekillendirilen kurumlarda, karşılıklı sadakat ve bağl1lık nasıl sürdürülür?” (2008: 11). $\mathrm{Bu}$ sorulardan hareketle ifade edilebilir ki Sennett'in iki farklı kapitalizm dönemini incelediği Karakter Aşınması isimli çalışmasında, baba-oğul ikilisi 


\section{Yeni Kentlileşme Sürecinde Kentli Karakter(ler)in Sosyolojik Yansımaları}

üzerinden bir karşılaştırmaya gitmesi, bireyin yeni kapitalist kentte nasıl bir kimliğe ve bir yaşam tarzına yöneldiğini açıklaması bakımından dikkat çekicidir. Sennett, bu çalışması ile eski ve yeni kapitalizmin çalışanlar üzerinde bıraktığı yoğun etkileri ortaya koymaya çalışmaktadır.

Sennett, bu çalı̧̧masında yeni kapitalist toplumsal yapının yüzeysel, kısa süreli ve güvensiz ilişkilerine dikkat çekmektedir. Bireyin bu sistemde istikrarlı tutum ve davranışlar sergileyemediğini, sürekli ve hızlı değişimlerdeki "geçiciliğin", daha çok kısa vadeli davranışları yaygınlaştırdığını detaylı bir şekilde açıklar. Sennett, eski kapitalist sistemde çalışan Enrico'nun rutin bir yaşam sürdüğünü ancak buna karşın huzurlu bir hayata sahip olduğunu vurgularken, yeni kapitalist sistemin temel kurucu ilkesini oluşturan esnek sistemde çalışan oğul Rico için durumların, bunun tam tersi olduğunu ifade eder. Geleceğe yönelik uzun vadeli planlara sahip olmayan Rico, istikrarlı bir hedef ve aile yaşantısında uzak, kaotik bir iklimde her an her şeyin değişebileceği kaygılı ve endişeli bir hayatı yaşamaktadır. Enrico'nun yaşam anlatısı, bürokratik bir dünya yaşantısına uygun ve doğrusal bir anlatı sunarken Rico'nun ise esneklik ve değişimin hâkim olduğu bir dünya anlatısı sunmaktadır (Sennett'den akt. Gül, 2019: 23). Her iki sistemin karakter üzerinde oluşturduğu etkiler iş yaşamından aile yaşamına, akraba ve cemaat içinde kurulan ilişkilere kadar yansımasını bulmaktadır.

Sennett'in üzerinde önemle durduğu konulardan biri "güven" duygusudur. Ona göre, "Güvenilir bir insan olmak için birilerinin bize ihtiyaç duyduğunu bilmemiz şarttır." Zira karakterimizle yakından alakalı olarak "bana kimin ihtiyaç duyduğu sorusu?", esnek sistemde yoğun saldırılar altında bulunmaktadır. Sistem insanlara kayıtsızlık duygusunu aşılamaktadır. Örneğin bunu, bir taraftan "kazananhepsini-alır" piyasalarında ödül ve risk arasındaki bağı keserek, insanın emeğini yararsız hale getirerek yapmaktadır. Diğer taraftan ise organizasyonlar veya kuruluşlarda karşılıklı ihtiyacı ve bağlılığ 1 yok ederek güvensizliği ve kayıtsızlığ 1 aşılamaktadır. $\mathrm{Bu}$ durum ise bireyin, başkalarına yararlı olduğu düşüncesini zedelemektedir. Nitekim yeni kapitalizm okunaksız ve parçalı bir sistem olduğu için çevreye yaydığı kayıtsızlık da kişiseldir. Nitekim Sennett'e göre eski kapitalist sistemde,

Enrico nerede durduğunu biliyordu; eski Yunan firıncılar, doğru veya yanlış, kimin dost kimin düşman olduğuna dair net bir fikre sahipti. Marksizmin eskiden, kişinin kafa karışıklığını 'yanlış bilinç’ olarak niteleme alışkanlığg vardır. Bu ifade asıl günümüz gerçekliğini tam olarak yansittyor (Sennett, 2008: 153-154).

Bir başka deyişle Sennett'e (2008: 146) göre yeni kapitalist sistemde herkes, toplumda kimin kendilerine ihtiyaç duyduğu sorusu karşısında kafa karışıklığ 1 yaşamaktadır. Çünkü bu sorunun bir karşılığının olması yani insanın "kendisine ihtiyaç duyan birilerinin olduğunu" bilmesi, kişide "güvenilir" olduğu hissini oluşturmaktadır. Güven bağları ise en çok da insanların sorun yaşadığı ve yardıma ihtiyaç duyduğu esnalarda önem kazanmaktadır. Ancak esneklik, güven 


\section{Hatice GÜL}

duygularını zayıflatarak, insanlara yalnız olduklarını hissettirmek suretiyle bu duyguyu yok etmektedir. Öte yandan esneklik anlayışı sadece güveni değil, güvenle birlikte bağlılık ve biz duygusunu da zedelemiştir. İşi vasıtasıyla bir türlü hayatını düzene oturtamayan Rico, bir tarafta taşındığ her semtte komşuluk ilişkilerinin zayıflığına şahit olmakta, diğer yandan cemaat ve aile değerleriyle özdeşleştirdiği "biz" duygusunu artık uygulanması mümkün olmayan statik bir soyutlama olarak görmektedir. Esasen Sennett'in baba ve oğul (eski ve yeni sistem) karakter karşılaştırması neticesinde ortaya koyduğu değerlendirmeleri göz önünde bulundurduğumuzda yeni kentli bireyin davranış kalıpları, yaşam tarzları ve manevi arayışlarında meydana gelen değişimler anlamlı görünmektedir.

Yeni kentli karakteriyle ilgili yaklaşım ve değerlendirmeler sadece Sennett ile sınırlı değildir. Bauman da çağdaş bireyin karakterini analiz ederken içinde bulunulan dönemin radikal değişimine vurgu yapmakta ve hiçbir şeyin bu değişimlerin dışında kalmadığını belirtmektedir:

Başka bir deyişle dünya eskisinden (ya da eskiden olduğunu düşündügümüzden) daha değişken görünüyor. Hayatın çeşitli yönlerinin anlamlı bir bütün oluşturacak biçimde birleşebildiği ve bugün yaşananların dünün köklerine ve yarının sonuçlarına bağlanabildiği zamanlarda açıkça görünen birlik ve sürekliliğini yitirdi. Bugün çoğumuz yaşadıklarımızdan şunları öğreniyoruz: Etrafimızda gördügümüz hiçbir biçim -ne kadar sağlam görünürse görünsün- değişimin dışında kalmıyor; şeyler bir anda ve hiç habersiz dikkat alanımıza giriyor ve ondan sonra da hiç iz bırakmadan unutuluyor; bugün çok moda olan şeyler yarının maskarası oluyor; bugün göklere çıkarılan ve şiddetle telkin edilen şeyler yarın aşağılanıyor (tabii eğer hatırlanırsa); zaman her birinin baş1 ve sonu bulunan fakat ne öncesi ne de sonras1 olmayan- vakalar halinde bölünüyor; bu vakalar arasında çok az mantıksal bağ bulunuyor ya da hiç bulunmuyor; ve bu vakalar, tıpkı ansızın ve bilinmedik yerlerden geldikleri gibi, arkalarında kalıcı sonuçlar bırakmadan kayboluyorlar. Başka bir deyişle, içinde yaşadığımız (hayat koşuşturmacalarımızla yarattığımız) dünya, parçalanmışlık, süreksizlik ve sonuçsalsızlık ile belirleniyor (Bauman, 2001: 341-342).

Bauman'ın da belirttiği gibi günümüzün yaşam tarzı ve değişim eğilimleri, içinde yaşanılan çevreye göre değişmektedir. Etrafımızda meydana gelen, sabit ve istikrarlı gibi gözüken her şey bir anda değişebilir. Bugün insanların önemsedikleri şeyler yarın önemsizleşmeye hatta hiç yaşanmamış gibi görünebilmektedir. Değişimin planlanmış bir zamanı yoktur. Her an her şey olabilir. Dolayısıyla bireyler de çevredeki değişimden doğrudan etkilenen aktörler haline gelmektedir. Bauman, içinde yaşadığımız koşullar altında şekillenen birden fazla karakter olduğunu öne sürmektedir. Ona göre "gezici, aylak, turist ve oyuncu" metaforları kimlik sürecinin giriftliğini aktaran karakterlerdir. Bu karakterler birbirlerinden farklı da olsalar, yine de birbirleriyle iç içe girmekte ve etkileşmektedirler. Bu sebeple söz konusu yaşam 


\section{Yeni Kentlileşme Sürecinde Kentli Karakter(ler)in Sosyolojik Yansımaları}

biçimlerinin birçok ortak özelliği bulunmaktadır. Bu yaşam biçimlerinin ne geçmiş ne de gelecek üzerinde etkileri vardır. İnsan ilişkilerini parça parça ve süreksiz olarak görmektedirler. Dolayısıyla dördü de kalıcı karş1lıklı bir yükümlülükler ağ oluşturmayı reddetmektedir (Bauman, 2001: 206). Bauman dünyayı bir oyun olarak kurgular. Oyuncu figürü de bu anlamda devreye girer. Oyun ne tam olarak öngörülebilir ne de tam olarak denetlenebilir ancak hiçbir şey sabit ve değiştirilemez de değildir. Oyunda tesadüfler olmaz. Ancak şans ve şansızlık gibi oyuncu ve dünya arasında hamleler vardır. Oyuncunun hedefi her zaman "bir adım önde" olmaktır, yani kazanmaktır. Başka bir deyişle oyuncunun dünyası, sezginin, risklerin ve önlem alma dünyasıdır. Oyunlar çeşitlidir, her oyunun bir anlam alanı bulunmakla birlikte bir başı ve sonu vardır. Oyunlar sonuçsal olmamalıdır. Her oyuncu, oyunun kalıcı sonuçları olmadığının, bunun sadece bir oyun olduğunu bilmelidir. Oyunda hiç kimse, geriye kin ve yara izi gibi olumsuz duygular bırakmamalı ve dostça ayrılmalıdır (2001: 133-135). Bauman'ın diğer karakteri ise “aylak”tır. Aylak gittiği her yere ait olmakta zorluk yaşar, daha doğrusu gittiği yerlerde bir yabancıdır. Nitekim aylak gittiği yerlerde aitliği istese de başaramaz. Bauman'a göre aylak bulunduğu yerde, daha önceki bulunduğu yerlerin kokusunu taşımaktadır. Aylağın yerlileşme isteği ise acı ile sonuçlanabilir. Bu yüzden tam bir yerlileşme, aylağın başarabileceği bir hedef değildir. Bundan dolayı aylağın yapacağı, bulunduğu yere bağlanmamasıdır. Bağlanmaması ona 'anlık' acılar verse de o, kendisine her zaman farklı yerler bulabilir. Belki ona gitmediği yerler daha fazla konuksever olabilir ve çeşitli imkânlar sunabilir. Bu yüzden "yersizlik stratejisi” onun için önemlidir (2001: 129-130). Bauman'ın diğer karakteri ise "turist" tir. Turist karakteri ile aylak karakteri birbirine benzemektedir. Turist de aylak gibi hareket halindedir. Ancak ikisini de birbirinden ayıran çeşitli farklılıklar vardır. Örneğin aylak için çoğunlukla "itme" faktörü ön planda iken turist için çekme faktörü öndedir. Bauman'a göre turist, sistematik ve bilinçli deneyim arayıcısıdır. Amacı yeni deneyimlerdir. Tattığı zevkler azaldıkça ve çekiciliklerini yitirdikçe farklı deneyimler ve zevkler aramaya başlar. Turist, kendisini yabancı ve garip yerlere bırakmak ister, tıpk1 kişinin kendisini denizin dalgasına bırakması gibi. Ancak tek bir şartla bunu yapar: "Haz verme yetisi sürdüğü müddetçe." Öte yandan turistin dünyas1, hoşnut edecek derecede esnek, turistin arzusu ile yoğrulan ve bir amaca hizmet edecek biçimde yaratılan dünyadır. Turistin dünyası tek başına ve tamamen estetik ölçüt ile yapılandırılmaktadır. Yani estetikleştirilmiş dünya, turistlerin ikamet ettiği dünyadır. Turisti, aylaktan ayıran bir diğer özellik ise evinin olmasıdır. Turistin macerası bittiğinde kendisine güven ve sıcaklık veren, gidebileceği bir evi olmalıdır. Turisti yeni maceraya iten şey ise bu güven veren evin dinginliğidir (2001: 130-132). Flâneur karakteri, yani "gezinen", Bauman'ın diğer metaforik karakteri ve modern kentin ürettiği bir kişiliktir. $\mathrm{O}$ da diğer karakterler gibi hareket halindedir. Flâneur, gezdiği yerlerdedir ama oraya ait değildir. Hem yaşamın hazlarını alan hem de bunun karşıllğında hiç acı çekmeyendir. Flâneur'un yaşam biçimini yükselten ve Flâneur ile gezinme arasında vazgeçilmez mekânsal bağı sağlayan şey ise alışveriş merkezleridir. Yeni kentsel hayat, esasen Flâneur'un gezinirken alışveriş yaptığı ve alışveriş yaparken gezindiği, güveni sağlayan yerler haline gelmiştir. Gezicinin bir 


\section{Hatice GÜL}

zamanlar yaptığ "gezinme" artık yeni kentsel yaşamın bizzat kendisi olmuştur (2001: 126-127).

Bauman' ın metaforik karakterlerinde görüldüğü üzere bireyler esas olarak tüketici/oyuncu olarak kurgulanmaktadır. Bir başka deyişle tüketiciler ve oyuncuların hepsinin ya da çoğunun, kendilerinden icra etmeleri istenen ve bunların icrası için eğitildikleri roller, karakter oluşumuna hizmet eden değerlendirmenin ana kalıplarını ve kriterlerini sağlamaktadır. Bauman bu şekilde betimlediği dünyada, bireyin oyuncu ve tüketici bir role büründügünü ve kendisinden yapılması beklenilen birtakım rollerinin olduğunu vurgular. Birey sürekli olarak yeni tecrübeler arayan, daimî uyarıcılara tepki verebilen, tecrübi bir organizma haline gelmiştir. Bireylerin özelliklerinden biri de kolayca harekete geçebilen bir davranış esnekliğine sahip, kazanılmış alışkanlıklarına ve önceki öğrendiklerine çok az bağlı olan yaratıcı aktörler olmalarıdır. Bireyler aynı zamanda birbirlerine bağlanmaktan ve paylaşım içinde olmaktan kaçınmaktadır, bir başka deyişle ötekine karşı ahlaki sorumluluk taşımamaktadırlar. Bireylerin, diğer bir ayırt edici özelliği ise kendi kendilerini güdüleyen ve kendilerine yeten biri olarak "bir dengeleme eğilimi” yani sosyalleşme süreci içerisinde bir iç düzenleme eğilimine sahip olmalarıdır. Dolayısıyla Bauman’a göre birey için en önemli doğruluk modeli uygunluk’tur. Uygunluk, gittikçe artan hılı değişimlere dayanma yetisiyle birlikte yeni tecrübeleri de bedensel ve ruhsal olarak içselleştirme kapasitesini temsil etmektedir (2001: 204-206).

Sennett ve Bauman dişında Fromm'un da çağdaş bireyin karakteriyle ilgili önemli değerlendirmeleri dikkat çekicidir. Fromm, bireyin tutum ve davranışlarıyla ilgili olarak sahip olma tutkusu ve eğilimini öne çıkararak bu kavrama büyük önem atfetmiştir. Fromm, bireyin toplumsal yönelimlerinde ortaya çıkan bu karakteristik eğilimini, özel mülkiyet anlayışına bağlar. Özel mülkiyetle kastedilen şey, sahip olunanı kendine ait kılmak ve saklamak, yani mülk edinmektir. Nitekim insan her şeye sahip olmak ister; inançlar, fikirler, eşyalar, mekânlar hatta evlilikler de bu "sahip olma" arzusuna dâhildir (Fromm'dan akt. Gül, 2019: 24-25). Sahip olma arzusu, tüketim alışkanlıklarının yarattığı geçici hazlar ve zevkler arasında geçişken bir özelliğe sahip olup aynı zamanda bir tatminsizlik hissi de barındırır. Dolayısıyla kentsel yaşamı devam ettirenlerin sürekli mekân değiştirmelerini ve tüketim ekonomisi bağlamında yeni çıkan her nesneye "sahip olma" arzularını da bu bağlamda değerlendirmek mümkündür (Gül, 2019: 25). Nitekim Harvey (2015: 117) de kentin, her türden insanın yan yana gelerek durmadan değişen, gelip geçici müşterek bir yaşantı tarzı ürettiğini vurgular. Bu şekilde Harvey, günümüz kentinin belirgin özeliklerini gelip geçici, müşterek bir yaşam tarzı ifadesiyle açık bir şekilde özetlemiştir. İnsanlar, değişen kent ortamında sınırsız biçimde sürekli bir şeylerin yerine ikame edebilecekleri yeni şeylere sahip olma güdüsüyle hareket etmektedirler. Sahip olma tutkusu, sınırsız bir tüketimle birlikte her an değişebilir yeni manevi isteklerle çevrili bir yaşam tarzı yaratmaktadır. Dolayısıyla bu tarz bir yaşamın alışkanlık haline gelmesi, bireyin manevi bir tatminsizlik ve arayış içerisinde olduğunun açık bir göstergesi olarak göz önünde bulundurulabilir (Gül, 2019: 25). 


\section{Yeni Kentlileşme Sürecinde Kentli Karakter(ler)in Sosyolojik Yansımaları}

Fromm (2005: 83), çağdaş dünyanın baskın karakterinin tasvirini yaparken onun, "pazarlamacı eğilim" yönüne dikkat çeker. Fromm'a göre pazarlamacı karakterin doğası ancak ekonomik piyasa koşullarını anlamakla mümkün olabilir. $\mathrm{Bu}$ anlamda pazarlamacı eğilimde "çağdaş pazar, kullanım değeri ve değiş-tokuş değeri” gibi kavramlar önemlidir. Pazar piyasasında iki ürün vardır; biri mal, diğeri ise kişiliktir. Fromm pazarlamacı karakteri, "insanın kendisini bir mal olarak görme tecrübesi içinde kök salmış karakter eğilimleri ve bir insanın değiş-tokuş değeri" olarak tanımlar. Fromm çağdaş dünyada "kişilik pazarı"nın çok önemli bir şekilde pazara eklendiğini de ileri sürmektedir. Ona göre yöneticiler, doktorlar, garsonlar, satıcılar, avukatlar ve sanatçıların hepsi bu pazarda görülmektedir. Onların mevkilerinin ve ekonomik koşullarının farklı olduğu bilindik bir gerçektir. Kimileri bağımsız kimileri ise bir yere bağlı olarak çalışır ve hizmetleri karşılığında ücret alırlar. Ancak hepsi de maddi başarıları için hizmetlerine gereksinim duyan kişilerin onaylarına ihtiyaç duymaktadırlar (2005: 82-83). Öte yandan pazarın değerlendirme ilkesi hem ürün pazarı hem de kişilik pazarı için de aynıdır. Her ikisinde de "değer", onların değiş-tokuş değeridir. Bu sebeple kullanım değeri gerekli olmakla birlikte şart da değildir. Kişilik pazarında başarılı olmak çok önemlidir, nitekim kişi talep edilmelidir. Eğer bir doktor muhteşem bir ofise sahip olup gerekli tıbbı donanıma ve bilgiye sahip değilse nasıl talep edilsin veya nasıl başarılı olabilsin! Başarılı olması için talep edilmelidir. Başarı ise bir insanın pazarda kendisini nasıl sattığına, kişiliğini nasıl iyi bir şekilde yansıttığına ve insanlara güzel bir "paket" sunup sunmamasına bağlıdır. Ayrıca neşeli, güvenilir, tutkulu, agresif olup olmadığı ile ilgili kişisel özelliklerinin yanı sıra kişinin aile geçmişi, kulüplerle üyeliği ve doğru insanlarla olan ilişkileri de talep edilmesinde önemli bir etkendir. Kişilik özellikleri bir dereceye kadar insanın çalışacağı özel alana bağlıdır. Yani bir satıcı, sekreter, borsac1, bir kolej profesörü, demiryolu yöneticisi veya bir otel müdürünün her biri çalıştıkları alanlarda farklı türlerde kişilik sergilemek zorundadırlar. Ancak hepsinin de bu farklılıklarına rağmen, yerine getirmek zorunda oldukları bir koşul vardır. $\mathrm{O}$ da "talep edilmek." Dolayısıyla başarılı olmak, "talep edilmek"tir. Bu durum ise aynı zamanda başkalarıyla rekabeti de gerektirir. Kısacası birey başkalarıyla yarışmalıdır da (2005: 84-85). Pazarcı eğilimde en önemli ve kalıcı özellik, davranışların değişebilir olmasıdır. Bu sebeple birey, daha çok talep gören bir rakibi karşısında kendini pazarlayabilecek özellikleri geliştirebilmeli ve gerekirse koşullara göre bu özellikleri değiştirmelidir de (2005: 92). Zira kişilik pazarında başarılı olmak çok önemlidir. Böylelikle çağdaş pazarın veya çağdaş dünyanın mottosu bizi şu sonuca götürmektedir: Başarılı olmak değerli, başarısız olmak ise değersizdir (2005: 87).

\section{Sonuç ve Değerlendirme}

Bu çalışmada yeni kapitalist kentleşmenin yoğun etkilerinin bir yansıması olarak ortaya çıkan "yeni kentli karakter(ler)i”nin başlıca özellikleri söz konusu edilmiştir. Bu süreçte kentsel hayata ilişkin tüketim ve haz ekseninde gelişen bireye özgü niteliklerin, giderek belirginleşen maneviyat arayışlarıyla olan ilişkisi öne çıkmıştır. Esasen yeni kapitalist sistemin istikrarsıllı̆̆a ve geçiciliğe yönelten yaşam tarzı ve davranış kodları, karakterler üzerinde yansımasını bulmaktadır. $\mathrm{Bu}$ 


\section{Hatice GÜL}

durumun, birey ve yeni kentsel dinamikler arasında yaşanan yeni maneviyat arayışlarına da işaret ettiğini belirtmeliyiz. Özellikle yeni kentlileşme kavramından bahsedilmesi ise bu bağlamda önemlidir. Zira kentli karakterlerin söz konusu yeni kapitalist süreçte karşılaştıkları sorunların bir yansıması olarak davranış ve tutumlarında meydana gelen değişimler, kentsel manevi huzursuzluğun göstergesi olarak okunabilir. Özellikle Bauman ve Fromm, bu konuyla ilgili ayrıntılı bir karakter tasvirine girişmiştir. Bauman'ın metaforik karakterleri, genel olarak yeni hazlar ve deneyimler arayan, kent içinde sürekli gezinen, alışverişi bir yaşam tarzı haline getiren, kazanılmış alışkanlıklarına ve önceki öğrendiklerine çok az bağlı, tüketici ve oyuncu özellikleriyle öne çıkmaktadır. Bauman için karakterlerin tüketici/oyuncu olması günümüz şartlarına ruhen ve bedenen uyum sağlamada önemlidir. Öte yandan Fromm için de çağdaş piyasada "karakter"den istenilen, iyi pazarlama yeteneğine sahip olması gerektiğidir. Burada kastedilen mesele, bireyin, kişiliğini piyasanın koşullarına göre değiştirip uyarlamasıdır. Pazar koşullarına uyum sağlamada, davranışlarında esnek ve yenilikçi olan, rekabetçi ve başarı odaklı düşünen pazarlamacı bireyleri, Bauman'ın “oyuncu metaforu”nda olduğu gibi Fromm'un karakter tasvirinde de görmek mümkündür. Diğer taraftan değişim ile süreklilik arasındaki yaşananları tecrübe eden kent insanını, Sennett; kısa vadeli planları olan, istikrarlı bir hedeften ve yaşantıdan uzak, sürekli bir değişim ve riske maruz kalan, kayıtsızlık ve güvensizlik gibi duygulara sahip bireyler olarak tasvir etmektedir. Bu durumda, Bauman ve Fromm'un tasvirlerinde olduğu gibi Sennett' in de çağdaş kentlinin mevcut özelliklerine vurgu yaparken, kentli karakterleriyle ilgili benzer ve ortak özellikleri öne çıkardığı görülmektedir.

\section{KAYNAKÇA}

ADLER, Alfred, Insanı Tanıma Sanatı, (Çev. Kamuran Şipal), 9. Basım, Say Yayınları, İstanbul 2002.

BAUDRILLARD, Jean, Tüketim Toplumu, (Çev. Hazal Deliceçaylı, Ferda Keskin), 6. Basım, Ayrıntı Yayınları, İstanbul 2013.

BAUMAN, Zygmunt, Parçalanmış Hayat: Postmodern Ahlâk Denemeleri, (Çev. İsmail Türkmen), Ayrıntı Yayınları, İstanbul 2001.

BERGER, Peter L., "Dinler ve Küreselleşme", (Çev. Hatice Gül), Bilimname: Düşünce Platformu, Cilt 2017, Say1 34, Ekim 2017, s. 603-613.

FROMM, Erich, Sahip Olmak ya da Olmak, (Çev. Aydın Arıtan), Arıtan Yayınevi, İstanbul 2003.

FROMM, Erich, Kendini Savunan İnsan, (Çev. Devrim Doğan Yüzer), İlya Yayınevi, İzmir 2005.

GÜNEŞ, Hasan, Sosyoloji Terimleri Sözlüğü, Ütopya Yayınevi, Ankara 2016.

GÜL, Hatice, Yeni Kentsel Ailenin Manevi Boyutlart: Gaziantep Örneği, Erciyes Üniversitesi Sosyal Bilimler Enstitüsü, Kayseri 2019 (Yayınlanmamış Doktora Tezi).

HAMBERG, Eva M., "Kilisesiz Ruhsallık”, (Çev. Yurdagül Mehmedoğlu), Din Sosyolojisi- Çăgdaş Gelişmeler (Der. Peter B. Clarke, Çev. Ed. İhsan Çapçıŏlu), İmge Kitabevi, Ankara 2012, s. 228-250. 


\section{Yeni Kentlileşme Sürecinde Kentli Karakter(ler)in Sosyolojik Yansımaları}

HAR VEY, David, Sosyal Adalet ve Şehir, (Çev. Mehmet Moralı), 4. Basım, Metis Yayınlar1, İstanbul 2013.

HARVEY, David, Asi Şehirler, (Çev. Ayşe D. Temiz), 4. Basım, Metis Yayınları, İstanbul 2015.

HILL, Peter C., Kenneth I. Pargament, Ralph W. Hood, Michael E. Mccullough, James P. Swyers, David B. Larson ve Brian J. Zinnbauer, "Din ve Maneviyat1 Kavramlaştırma: Birleşme ve Ayrılma Noktaları", (Çev. Nurten Kimter), Çanakkale Onsekiz Mart Üniversitesi Illahiyat Fakültesi Dergisi, Say1 3, 2013, s. 85-118.

KELEŞ, Ruşen, Kent Bilimleri Terimler Sözlüğ̈̈, TDK Yayınları, Ankara 1980.

KUMAR, Krishan, Sanayi Sonrası Toplumdan Post-Modern Topluma: Çă̆daş Dünyanın Yeni Kuramları, (Çev. Mehmet Küçük, Dost Yayınları, Ankara 1999.

MARSHALL, Gordon, Sosyoloji Sözlüğü, (Çev. Osman Akınhay, Derya Kömürcü), Bilim ve Sanat Yayınları, Ankara 1999.

PARGAMENT, Kenneth I., "Din Psikolojisi mi, Din ve Maneviyat Psikolojisi mi? Gerekçeler ve İtirazlar”, (Çev. Ahmet Rifat Geçioğlu), Bilimname: Düşünce Platformu, Cilt 29, Say1 2, 2015, s. 365-382.

ROBINS, Kevin, Into The Image: Culture and Politics in The Field of Vision, Routledge, London 1996.

SENNETT, Richard, Karakter Aşınması: Yeni Kapitalizmde İşin Kişilik Üzerindeki Etkileri, (Çev. Barış Yıldırım), 3. Basım, Ayrıntı Yayınları, İstanbul 2008.

TAYLOR, Charles, Modern Toplumsal Tahayyüller, (Çev. Hamide Koyukan), Metis Yayınları, İstanbul 2006.

VARGA, Ivan, "Georg Simmel: Religion and Spiritüality", A Sociology of Spiritüality, (Ed. Kieran Flanagan, Peter C. Pupps), Ashgate Publishing Limited, England 2007, p. 145-160. 